\title{
FasL (CD95L/APO-1L) Resistance of Neurons Mediated by Phosphatidylinositol 3-Kinase-Akt/Protein Kinase B- Dependent Expression of Lifeguard/Neuronal Membrane Protein 35
}

\author{
Christoph P. Beier, ${ }^{1}$ Jörg Wischhusen, ${ }^{2}$ Marc Gleichmann, ${ }^{1}$ Ellen Gerhardt, ${ }^{1,3}$ Ana Pekanovic,,${ }^{1,3}$ Andreas Krueger, ${ }^{4}$ \\ Verdon Taylor, ${ }^{5}$ Ueli Suter, ${ }^{5}$ Peter H. Krammer, ${ }^{4}$ Matthias Endres, ${ }^{6}$ Michael Weller, ${ }^{2}$ and Jörg B. Schulz ${ }^{1,3}$ \\ Laboratories of ${ }^{1}$ Neurodegeneration and ${ }^{2}$ Molecular Neurooncology, Department of Neurology, Medical School, University of Tübingen, 72076 Tübingen, \\ Germany, ${ }^{3}$ Department of Neurodegeneration and Restorative Research, Center of Molecular Physiology of the Brain and Center of Neurological Medicine, \\ University of Göttingen, 37073 Göttingen, Germany, ${ }^{4}$ Division of Immunogenetics, Tumor Immunology Program, German Cancer Research Center, 69120 \\ Heidelberg, Germany, ${ }^{5}$ Institute of Cell Biology, Department of Biology, Eidgenössische Technische Hochschule, 8093 Zürich, Switzerland, and \\ ${ }^{6}$ Department of Neurology, Charité, Humboldt University, 10117 Berlin, Germany
}

The contribution of Fas (CD95/AP0-1) to cell death mechanisms of differentiated neurons is controversially discussed. Rat cerebellar granule neurons (CGNs) express high levels of Fas in vitro but are resistant to FasL (CD95L/AP0-1L/CD178)-induced apoptosis. We here show that this resistance was mediated by a phosphatidylinositol 3-kinase (PI 3-kinase)-Akt/protein kinase B (PKB)-dependent expression of lifeguard (LFG)/neuronal membrane protein 35. Reduction of endogenous LFG expression by antisense oligonucleotides or small interfering RNA lead to increased sensitivity of CGNs to FasL-induced cell death and caspase-8 cleavage. The inhibition of PI 3-kinase activity sensitized CGNs to FasL-induced caspase- 8 and caspase- 3 processing and caspase-dependent fodrin cleavage. Pharmacological inhibition of PI 3-kinase, overexpression of the inhibitory protein $\mathrm{I} \kappa \mathrm{B}$, or cotransfection of an LFG reporter plasmid with dominantnegative Akt/PKB inhibited LFG reporter activity, whereas overexpression of constitutively active Akt/PKB increased LFG reporter activity. Overexpression of LFG in CGNs interfered with the sensitization to FasL by PI 3-kinase inhibitors. In contrast to CGNs, 12 glioma cell lines, which are sensitive to FasL, did not express LFG. Gene transfer of LFG into these FasL-susceptible glioma cells protected against FasL-induced apoptosis. These results demonstrate that LFG mediated the FasL resistance of CGNs and that, under certain circumstances, e.g., inhibition of the PI 3-kinase-Akt/PKB pathway, CGNs were sensitized to FasL.

Key words: apoptosis; Fas/CD95; lifeguard; cerebellar granule neurons; PI 3-kinase/Akt; caspase

\section{Introduction}

Fas (CD95/APO-1) and FasL (CD95L/APO-1L/CD178) are a cytokine receptor/cytokine pair of the tumor necrosis factor/nerve growth factor (TNF/NGF) superfamily. Natural mouse mutants

Received Dec. 30, 2004; revised June 1, 2005; accepted June 1, 2005.

This study was supported by grants from the Deutsche Forschungsgemeinschaft to J.B.S. (Schu 932/2, SFB 430 Center of Molecular Physiology of the Brain) and M.W. (We 1502/10-2). U.S. was supported by the Swiss National Science Foundation and the National Center of Competence in Research Neural Plasticity and Repair. M.E. was supported by the Deutsche Forschungsgemeinschaft (Heisenberg-Program, En 343/7-1) and the Volkswagen Stiftung (Lichtenberg Programme).

Correspondence should be addressed to Dr. Jörg B. Schulz, Department of Neurodegeneration and Restorative Research, Deutsche Forschungsgemeinschaft Research Center/Molecular Physiology of the Brain, University of Göttingen, Waldweg 33, D-37073 Göttingen, Germany. E-mail: jschulz4@gwdg.de.

C. P. Beier's present address: Department of Neurosurgery, Medical School, University of Regensburg, 93047 Regensburg, Germany.

A. Krueger's present address: Department of Cancer Immunology and AIDS, Dana-Farber Cancer Institute, Boston, MA 02115.

V. Taylor's present address: Department of Molecular Embryology, Max Planck Institute of Immunobiology, D-79108 Freiburg, Germany.

D01:10.1523/JNEUROSCI.1700-05.2005

Copyright $\odot 2005$ Society for Neuroscience $\quad$ 0270-6474/05/256765-10\$15.00/0 for Fas (lpr) and FasL (gld) exhibit a syndrome resembling the human autoimmune disease systemic lupus erythematosus, indicating a role for Fas/FasL interactions in the limitation of exogenously triggered immune responses. Fas mutations may cause an autoimmune lymphoproliferative syndrome in humans (Drappa et al., 1996; Clementi et al., 2004; Holzelova et al., 2004). FasL is abundantly expressed in the nervous system (Bechmann et al., 1999), and its presence has been related to the maintenance of immune privilege in the CNS through its ability to trigger the death of invading lymphocytes (French et al., 1996; Saas et al., 1997; Weller et al., 1997; Green and Ferguson, 2001). The cognate death receptor Fas has also been detected in the nervous system. Specific neuronal populations in postnatal mouse brain express Fas mRNA and protein even in nonlesioned animals (Park et al., 1998; Cheema et al., 1999; Felderhoff-Mueser et al., 2000). However, $l p r$ and gld mice appear to show no obvious neuronal phenotype (Kovac et al., 2002).

Neurons appear to be sensitive to FasL during development and before differentiation (Cheema et al., 1999; Raoul et al., 1999, 2002). However, during in vitro maturation and differentiation at 
least, motor neurons become resistant to FasL-induced apoptosis (Raoul et al., 1999). This acquired resistance was attributed to the upregulation of the caspase-8/FLICE (Fas-associated death domain-like IL-1 $\beta$-converting enzyme) inhibitory protein (FLIP). Under certain pathological conditions, FasL-induced apoptosis has been implicated in cell death of mature neurons. $l p r$ and gld mice and mice treated with anti-FasL antibodies are protected from focal ischemia in vivo (Martin-Villalba et al., 1999, 2001).

We and others reported previously that, like mature motor neurons in culture, differentiated cerebellar granule neurons (CGNs) cultured for $7 \mathrm{~d}$ were not sensitive to FasL (Gerhardt et al., 2001; Putcha et al., 2002). This has been questioned by others (Le-Niculescu et al., 1999; Hou et al., 2002). We here wanted to test the mechanisms of this resistance. In addition to FLIP, lifeguard (LFG) is an endogenous inhibitor of Fas-mediated apoptosis in tumor cells (Somia et al., 1999). LFG was isolated as a gene from a human lung fibroblast cell line, MRC5, that was not sensitive to FasL. Somia and colleagues showed that LFG bound directly to the Fas receptor but not to Fas adaptor proteins. Its rat homolog was identified as a protein upregulated during the development of spinal motor neurons of the sciatic nerve. Although it is expressed and upregulated during development in the CNS (Somia et al., 1999; Schweitzer et al., 1998, 2002), its antiapoptotic function and mechanisms of its temporal expression profile in the CNS have never been investigated. We here tested the hypothesis that LFG provides protection from neuronal apoptosis and investigated potential mechanisms of the regulation of Fas expression.

\section{Materials and Methods}

Materials. Unless otherwise stated, all materials were obtained from Sigma (Deisenhofen, Germany). The antibodies to LFG were described previously (Schweitzer et al., 1998, 2002). They were raised against a synthetic peptide in the $\mathrm{N}$-terminal loop of neuronal membrane protein 35 (NMP35) (SYEEATSGEGLKAGAF). The Fas antibody used for immunocytochemistry (catalog \#610197) was obtained from BD Transduction Laboratories (Lexington, KY); the Fas antibody (clone C-20, sc-715) used for immunoprecipitation and the antibody against c-myc (sc-40) were purchased from Santa Cruz Biotechnology (Santa Cruz, CA). The antibodies against the flag epitope (catalog \#200472) were from Stratagene (La Jolla, CA), against caspase-8 (SK 441) from SmithKline Beecham Pharmaceuticals (gift from K. K. Kikly, King of Prussia, PA), against c-FLIP (catalog \#1159) from ProSci (San Diego, CA), and against fodrin (mab-1622) and neuronal-specific nuclear protein (NeuN) (mab377) from Chemicon (Temecula, CA).

Constructs. The generation of pBCMGS-Apo-1 has been described previously (Weller et al., 1995). pSG5-contitutionally active (gag)protein kinase $\mathrm{B}(\mathrm{PKB}) / \mathrm{Akt}$ and pSG5-HA-dominant-negative (DN) PKB/Akt (kinase dead 388) plasmids were generous gifts from Dr. Boudewijn Burgering (Utrecht, The Netherlands); pcDNA3-I $\kappa$ B, pFLIP (s), and pFLIP (l) were obtained from Peter Daniel (Berlin, Germany) and Jürg Tschopp (Lausanne, Switzerland). For all other constructs the vector pcDNA 3.1 or a modified 6x-myc-pcDNA 3.1 were used (Invitrogen, Karlsruhe, Germany). In the latter, six repeats of c-myc were cloned into pcDNA 3.1 by using the HindIII and BamH1 sites of the multiple cloning site. The $L F G$ construct was cloned by using cDNA of rat CGNs. The fragment was amplified with the following primers: up, $5^{\prime}$-TTT GAA TTC TCC TCA TTC CCG GTT GGT GC-3'; and down, 5'-TTT GGA TCC TCG AGA GAC GAC ACC ATG AC-3'.

Generation of pSUPER-LFG (525-545). The small interfering RNA (siRNA) target sequence was 525-545 (5'-AACCTGATTCTGCTGACCATC-3'). The 64-mer oligos 5'-GATCCCCCCTGATTCTGCTGACCATCTTCAAGAGAGATGGTCAGCAGAATCAGGTTTTTGGAAA-3' and 5'-TCGATTTCCAAAAACCTGATTCTGCTGACCATCTCTCTTGAAGATGGTCAGCAGAATCAGGGGG-3' were obtained from MWG Bio- tech (Ebersberg, Germany), annealed, phosphorylated, and ligated into BglII and SalI sites of pSUPER (Brummelkamp et al., 2002). The sequence was chosen according to the guidelines published by T. Tuschl (http://www. rockefeller.edu/labheads/tuschl/sirna.html). Integrity of the insert was confirmed by sequencing on an ABI310 capillary sequencer using Big Dye Sequencing Mix (ABI Prism; PerkinElmer Life Sciences, Überlingen, Germany).

Northern blot analysis. Total RNA was extracted using the RNeasy RNA purification system (Qiagen, Hilden, Germany). Denatured total RNA $(10 \mu \mathrm{g})$ was loaded on a $1 \%$ agarose gel containing $6.7 \%$ formaldehyde. The RNA was separated at $100 \mathrm{~V}$, transferred to a Hybond N+ membrane (Amersham Biosciences, Freiburg, Germany) by capillary blotting, and cross-linked in a UV stratalinker 1800 (Stratagene) at 1200 J. Methylene blue staining was performed as a loading control. The membrane was preincubated for $2 \mathrm{~h}$ in Church buffer at $65^{\circ} \mathrm{C}$. Full-length rat LFG was labeled using $5 \mu \mathrm{l}(\sim 1.6 \mathrm{MBq}) \mathrm{dCTP}$ and the Rediprime II random labeling system (Amersham Biosciences). Filters were hybridized overnight at $65^{\circ} \mathrm{C}$ in a hybridization oven with a rotisserie device using Church buffer. Binding of radioactive probes was visualized and quantified using a PhosphoImager (FujiBasReader 1500; Fuji, Kangawa, Japan).

Quantitative reverse transcription-PCR. Total RNA was extracted with standard protocol using Trizol reagent (Invitrogen, Karlsruhe, Germany). Reverse transcription was performed with iScript cDNA Synthesis kit (Bio-Rad, Munich, Germany). Quantitative analysis of gene expression relative to a cDNA template was performed by reverse transcription (RT)-PCR using the Stratagene Mx3000P thermal cycler. The housekeeping gene glyceraldehyde-3-phosphate dehydrogenase $(G A P D H)$ was used as an internal standard for antisense experiments (taken from RTPrimerDB, Real Time PCR Primer and Probe Database). The sense primer for GAPDH was 5' -ATGATTCTACCCACGGCAAG$3^{\prime}$, and the antisense primer was $5^{\prime}$-CTGGAAGATGGTGATGGGTT-3'. The housekeeping gene actin was used as an internal standard for determination of $L F G$ in cerebellum. The actin sense primer was $5^{\prime}$ ATTGCCGACAGGATGCAGAA- ${ }^{\prime}$, and the antisense primer was $5^{\prime}$ GCTGATCCACATCTGCTGGAA- $3^{\prime}$. LFG and Fas primers were created using Primer Express software (Applied Biosystems, Foster City, CA): LFG, sense primer, 5' - CATCCTCCTGCCCTTCCAAT-3'; antisense primer, 5' - CACACCCGCTCCTAGCACA-3'; Fas receptor, sense primer, 5' - CCCAGAATACCAAGTGCAGGTG-3'; antisense primer, 5'-TGTGCAAGGCTCAAGGATGTC-3'. The relative RNA expression levels were calculated using the $\Delta \mathrm{CT}$ (difference of cycle thresholds) method, and the average results from three samples for each condition are shown.

Cell culture and survival assays. CGNs were obtained from 7-d-old Sprague Dawley rats and cultured as described previously (Schulz et al., 1996). All experiments with CGNs were performed on day in vitro (DIV) 8. The viability of CGNs was assessed by fluorescein diacetate (FDA) staining (Gerhardt et al., 2001). HEK-293, PC12, N2A murine neuroblastoma, and LN-18 human glioma cells were cultured in DMEM supplemented with $10 \%$ FCS and penicillin $(100 \mathrm{U} / \mathrm{ml}) /$ streptomycin $(100 \mu \mathrm{g} /$ $\mathrm{ml}$ ). All cell lines were seeded at $6 \times 10^{5} \mathrm{cells} / \mathrm{cm}^{2}$. To ectopically express LFG in LN-18 cells, the cells were transfected using Effectene transfection reagent (Qiagen), followed by selection with $100 \mu \mathrm{g} / \mathrm{ml} \mathrm{G418.} \mathrm{Stable}$ expression of LFG was assessed by immunocytochemistry. The survival of LN-18 cells was measured by crystal violet staining (Weller et al., 1994). In brief, supernatant was removed, and the cells were incubated for $10 \mathrm{~min}$ in $2 \%$ of crystal violet dissolved in $20 \%$ methanol. The plates were washed in running tap water and air dried for $24 \mathrm{~h}$. After addition of $0.1 \mathrm{~m}$ sodium citrate buffer, OD values were read at $550 \mathrm{~nm}$ on a Dynatech (Denkendorf, Germany) plate photometer.

Production of FasL. FasL was obtained from FasL-transfected murine N2A neuroblastoma cells, which secrete high amounts of soluble FasL into the supernatant (Rensing-Ehl et al., 1995; Schneider et al., 1998). One unit is defined as the activity of FasL required to kill $50 \%$ of LN-18 glioma cells in $100 \mu$ l volume 96-well assays.

LFG antisense studies. An LFG antisense phosphothioate oligonucleotide complementary to the region around the initiation codon (5'-GAG CTT TCC CCG GGT CAT GG-3') of LFG was purchased from MWG 
Biotech. A scrambled oligonucleotide composed of the same nucleotides ( $5^{\prime}$-CGT ATT GCC ATG CGG CGT CTC-3') was used as a control. The sequence is not complementary to any eukaryote mRNA as controlled with the National Center for Biotechnology Information basic local alignment search tool Blast (http://www.ncbi.nlm.nih.gov/BLAST). Both oligonucleotides contained three phosphothioate linkages at the $3^{\prime}$ and the $5^{\prime}$ ends. The $5^{\prime}$ ends of both oligonucleotides were conjugated to fluorescein to monitor the transfection efficacy.

Western blot and coimmunoprecipitation. Western blotting was performed according to standard procedures (Gerhardt et al., 2001). For immunoprecipitation, HEK-293 cells were seeded in $10 \mathrm{~cm}^{2}$ dishes. On the next day, the cells were transfected with $2 \mu \mathrm{g}$ of plasmid using Effectene transfection reagent (Qiagen). The cells were collected $48 \mathrm{~h}$ later and lysed for $45 \mathrm{~min}$ on ice $(140 \mathrm{~mm} \mathrm{NaCl}, 20 \mathrm{~mm}$ Tris $\mathrm{HCl}, 1 \mathrm{~mm} \mathrm{CaCl}$, and $0.5 \%$ $\mathrm{NP}-40)$. After spinning down the pellet (13,000 $\left.\mathrm{min}^{-1}, 4^{\circ} \mathrm{C}, 10 \mathrm{~min}\right), 250 \mu \mathrm{l}$

A

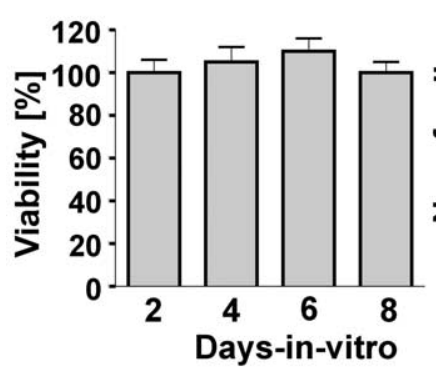

C

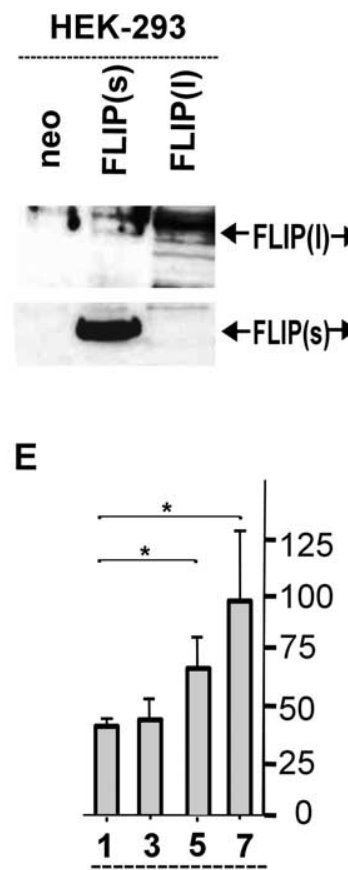

Days-in-vitro
B
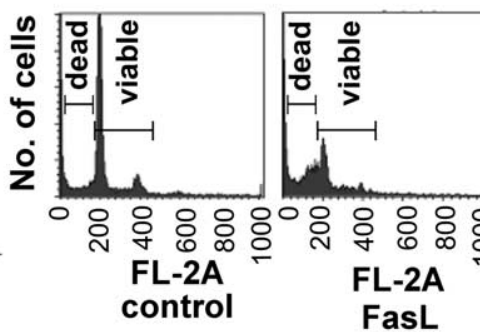

D
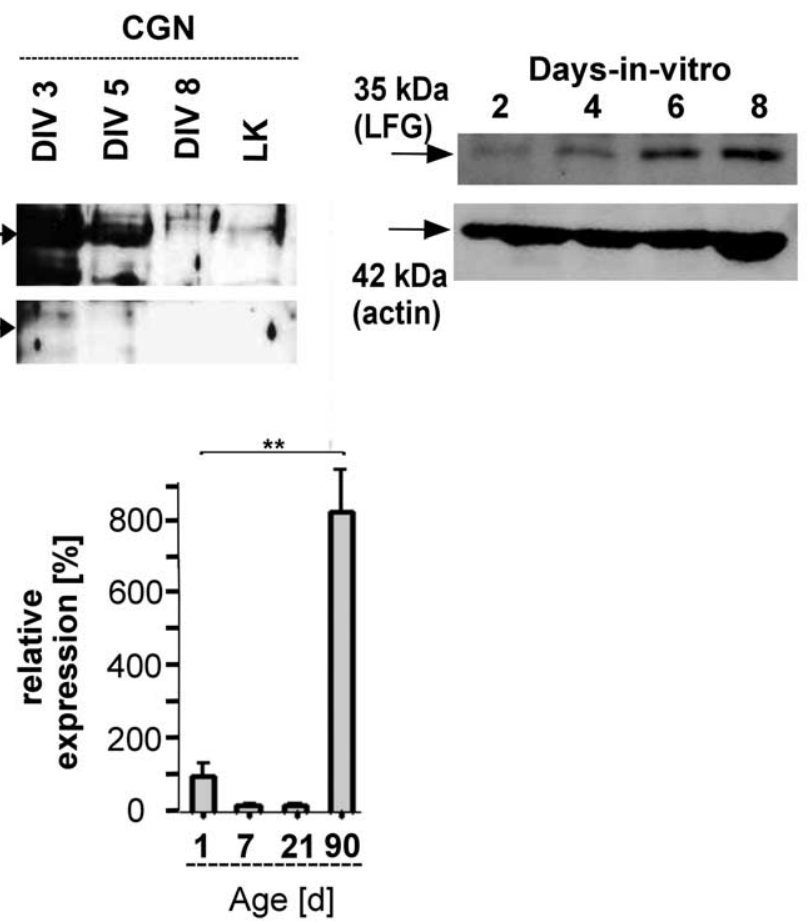

Figure 1. Resistance of CGNs against FasL-induced apoptosis and expression of LFG. $\boldsymbol{A}$, The resistance of CGNs cultured in medium containing $10 \% \mathrm{FCS}$ to $500 \mathrm{U} / \mathrm{ml} \mathrm{FasL}$ did not change in the course of in vitro maturation. CGNs were resistant to $500 \mathrm{U} / \mathrm{ml}$ FasL at all time points ( $n=3$ per time point). $\boldsymbol{B}$, To test the cross-reactivity of human FasL used in the experiments with rat Fas, rat lymphocytes isolated from spleens of 8-d-old rats were coincubated with FasL. Cell death was detected as the sub- $G_{0} / G_{1}$ peak by propidium iodide staining and flow cytometry at $16 \mathrm{~h}$. C, D, The temporal profile of FLIP (long), FLIP (short), and LFG expression in CGNs was studied by Western blot analysis. Lysates from CGNs were prepared at the time points indicated, and $30 \mu \mathrm{g}$ of protein was used per lane. As positive control lysates of HEK-293, cells were transfected with FLIP (long) and FLIP (short) using Effectene. FLIP was expressed in CGNs until DIV 5 but was no longer detected at DIV 8. In contrast, expression of LFG was upregulated from DIV 2 to DIV 8. E, LFG mRNA expression in CGNs in vitro (left) and in the cerebellum in vivo (right) during maturation. LFG $\mathrm{mRNA}$ expression was assessed using RT-PCR and compared with GAPDH expression (in vitro) or actin expression (in vivo) shown as relative data ( $n=3$ per time point; ${ }^{*} p<0.05,{ }^{* *} p<0.001$, ANOVA followed by Scheffe's post hoc test.).

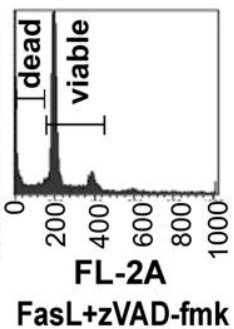

of the supernatant were incubated for $2 \mathrm{~h}$ on ice with $1.5 \mu \mathrm{g}$ of Fas antibody (C-20; Santa Cruz Biotechnology). Agarose-coupled A/G protein (Santa Cruz Biotechnology) was added, and, $1 \mathrm{~h}$ later, the pellet was washed three times with PBS and protease inhibitors. All samples $(30 \mu \mathrm{g})$ were denaturted using $1 \%$ SDS/1\% mercaptoethanol and used for Western blotting.

Immunocytochemistry. Cells were seeded on coverslips and transfected er rinsing with PBS, cells were fixed with $4 \%$ paraformaldehyde for 5 Triton X-100), and incubated overnight with antibodies against Fas (1: $1000)$ or LFG (1:500) in PBS containing $1 \%$ serum and $0.1 \%$ Triton $\mathrm{X}-100$. After washing with PBS, the sections were incubated at room temperature for $2 \mathrm{~h}$ with carbocyanine 2- and/or 3-labeled secondary antibodies (Biotrend, Cologne, Germany). Cells were analyzed by confocal laser scanning microscopy (LSM 510; Zeiss, Jena, Germany).

Transfection methods and flow cytometry. CGNs were transfected using $\mathrm{CaCl}_{2}$ or the GeneGun as described previously (Kohrmann et al., 1999; Gleichmann et al., 2002) as indicated. The oligonucleotides were delivered into CGNs using Effectene transfection reagent (Qiagen). Tumor cells were transfected using FuGene (Roche, Mannheim, Germany).

For flow cytometry, LN-18 cells were seeded in 24-well plates. On the next day, they were transfected with $0.3 \mu \mathrm{g}$ of DNA per well $[0.1 \mu \mathrm{g}$ of green fluorescent protein (GFP) and $0.2 \mu \mathrm{g}$ of the plasmid of interest or the control plasmid] using Effectene. After 24 h, 50 U/ml FasL was added, and, $18 \mathrm{~h}$ later, both adherent and floating cells were collected. The cells were once washed with PBS, fixed with $4 \%$ formaldehyde for $5 \mathrm{~min}$, and washed with PBS and PBS containing $0.1 \%$ Triton $\mathrm{X}-100$. The cells were then incubated for $30 \mathrm{~min}$ in PBS containing $1 \%$ propidium iodide and $1 \%$ RNase A and analyzed on a FACSCalibur (Becton Dickinson, Franklin Lakes, NJ).

Reporter gene assays. The predicted promoter fragment of $L F G$ (www.genomatix.com) was amplified from rat genomic DNA using the following primers: up, 5'-GTCCGGGAACCCTGATAGA3'; and down, 5'-GAGTCAGGAGAGGATGCT$3^{\prime}$. The resulting fragment was further amplified in a nested PCR with the primer pair $5^{\prime}$ TTTCTCGAGCTCAGTCAATGG-3' (up) and 5'-TCTAAGCTTATAGCAGGGAAG-3' (down) and cloned into the XhoI and HindIII sites of pGL3-basic (Promega, Mannheim, Germany). For the assay, PC12 cells were seeded into 96-well plates $\left(2 \times 10^{4}\right.$ cells per well $)$ and left to adhere overnight, before they were cotransfected with $0.08 \mu \mathrm{g}$ of LFG-Luc reporter gene plasmid, 0.02 $\mu \mathrm{g}$ of the respective activator plasmid (or irrelevant DNA), and $0.02 \mu \mathrm{g}$ of pRL-cytomegalovirus (CMV) (Promega), using FuGene 6 (Roche). At $32 \mathrm{~h}$ after transfection, the cells were treated as indicated. Another $16 \mathrm{~h}$ later, Reporter Lysis Buffer (Promega) was added, and cell lysates were transferred to a LumiNunc plate (Nunc, Roskilde, Denmark). The respective activities of firefly and renilla reniformis luciferase were determined sequentially in a LumimatPlus (Berthold, Pforzheim, Germany) using a noncommercial dual luciferase assay (Dyer et al., 2000). Luciferin, coenzyme A, and coelenterazine were all from PJK (Kleinblittersdorf, Germany). Background was subtracted from all values, and the counts obtained from the measurement of firefly luciferase were normalized with respect to pRL-CMV. 

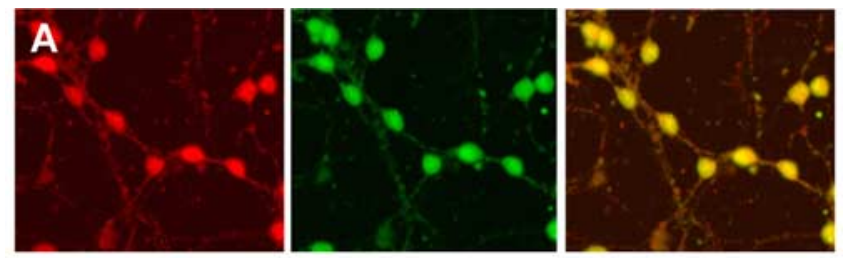

B
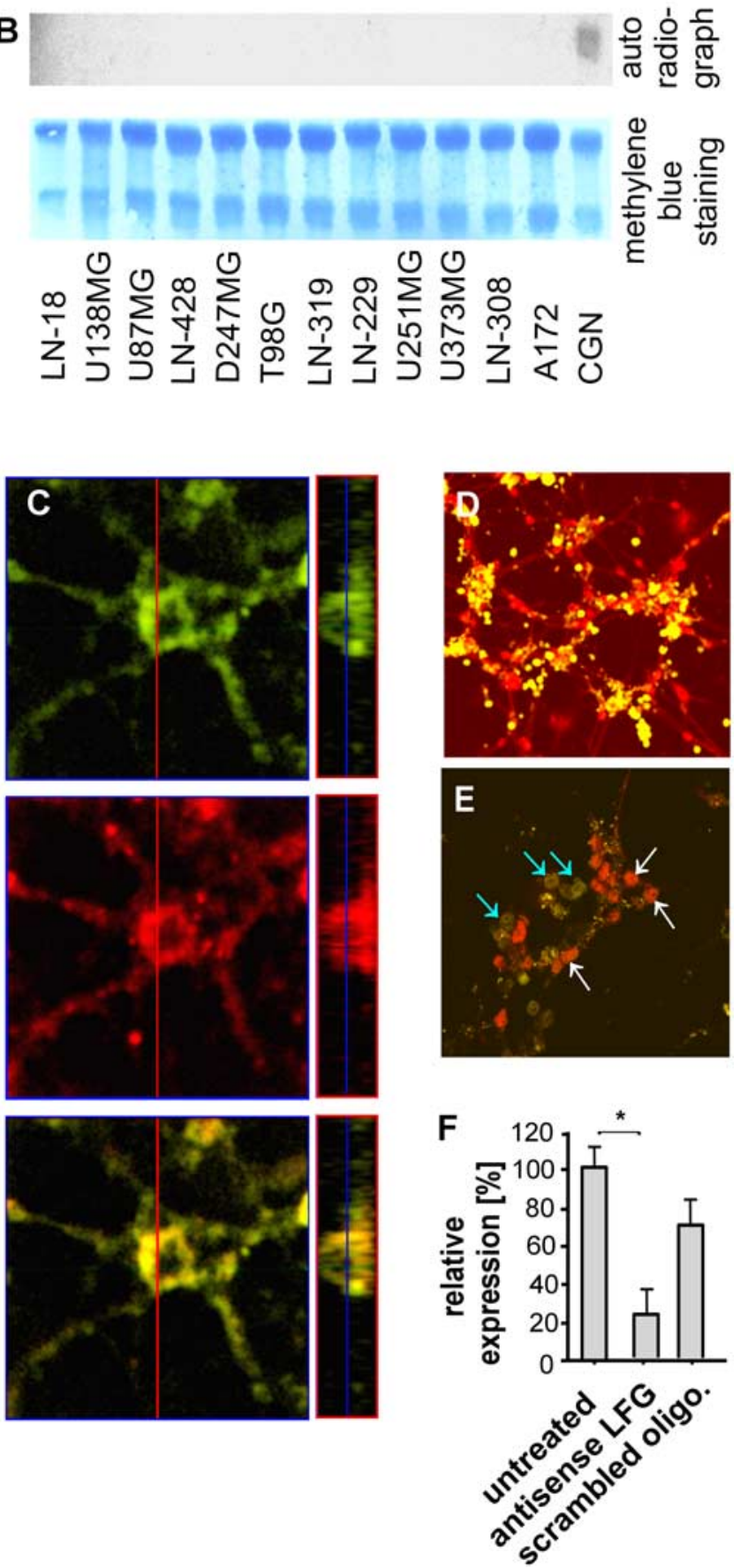

Figure 2. Colocalization of LFG and Fas in CGNs. A, CGNs were stained for LFG (green) and $\mathrm{NeuN}$ (red). All LFG-positive cells showed colocalization with NeuN (yellow). $\boldsymbol{B}$, In contrast to all glioma cell lines tested, CGNs expressed LFG mRNA, as shown by Northern blot analysis. Methylene blue staining was performed as a loading control. C, Confocal image of Fas (red)-labeled and LFG (green)-labeled CGNs viewed in three dimensions after orthogonal reconstruction of $z$-scans with a thickness of $0.77 \mu \mathrm{m}$. There is colocalization of both stainings in neurites, cytoplasm, and the cell membrane. $\boldsymbol{D}, \boldsymbol{E}$, Fluorescein-labeled antisense oligonucleotides (green) efficiently transfected CGN. Antisense oligonucleotides to LFG reduced the LFG levels in CGN.
Statistical analysis. Data are expressed as mean \pm SEM. Statistical analysis was assessed by one-way ANOVA, followed by Scheffe's post hoc test If not otherwise stated, all experiments reported were done with $n=3$ per group or time point and represent one of at least three independent replications.

\section{Results}

Differentiated CGNs are resistant to FasL-induced apoptosis We reported previously that potassium withdrawal-induced neuronal death is not altered in lpr and gld mice or by pharmacological inhibition of caspase- 8 and that CGNs are resistant to exogenous FasL (Gerhardt et al., 2001). CGNs express Fas (LeNiculescu et al., 1999; Gerhardt et al., 2001; Hou et al., 2002), but the exposure of CGNs to up to $500 \mathrm{U} / \mathrm{ml}$ FasL did not induce cell death (data not shown). To investigate whether the inhibition of the events leading to cell death in CGNs occurred upstream or downstream from the activation of caspases, we studied the processing of fodrin (also called spectrin), a specific substrate of caspase-3 (Jänicke et al., 1998). We did not detect any fodrin cleavage after the addition of up to $500 \mathrm{U} / \mathrm{ml}$ FasL for $24 \mathrm{~h}$ (data not shown). Because the level of Fas expression as well as of inhibitory molecules varies during neuronal maturation (Cheema et al., 1999), we investigated whether the sensitivity of CGNs changed during their in vitro maturation. No alteration was found from DIV 2 to DIV 8 (Fig. $1 A$ ). As a positive control for the effects of FasL on rat cells, we ascertained that lymphocytes from rat spleen undergo zVAD-fmk ( $N$-benzyloxycarbonyl-Val-Ala-Aspfluoromethyl ketone)-sensitive apoptosis in response to treatment with 50-500 U/ml FasL (Fig. $1 B$ ).

\section{Endogenous LFG protects CGNs against FasL}

To further investigate the mechanisms of resistance to FasLmediated cell death in CGNs, we studied proteins that are known to confer resistance to FasL. The resistance of differentiated motor neurons to FasL is linked to the expression of FLIP (Raoul et al., 1999). The long isoform of FLIP was expressed in CGNs until DIV 5 but became undetectable at DIV 8 (Fig. 1C). Because the resistance of CGNs to FasL was unaltered during this period, we expected another protein to mediate resistance to FasL. A candidate protein was LFG, which inhibits the Fas-dependent killing pathway via an unknown mechanism (Somia et al., 1999). Its rat homolog, NMP35, is abundantly expressed in the CNS (Schweitzer et al., 1998) but has not yet been linked to neuronal apoptosis. In contrast to FLIP, protein expression of LFG was upregulated during the maturation of CGNs from DIV 2 to DIV 8 (Fig. $1 D, E$ ). This corresponds to a gradual increase in LFG protein expression in brain lysates taken from postnatal day 7 (P7), P14, P21, and P60 (Schweitzer et al., 1998). Using quantitative PCR, we found that this increased expression was caused by a transcriptional upregulation in CGNs in vitro and in the cerebellum in vivo (Fig. $1 E$ ). In contrast, Fas receptor expression remained unchanged during in vitro maturation (data not shown). Using an antibody (Schweitzer et al., 1998, 2002) against LFG, we detected LFG expression in all cultured CGNs (Fig. 2A)

After transfection, the uptake of oligonucleotides was reflected by green fluorescence. Cells were fixed and stained for LFG (red). Those neurons with a strong uptake of fluorescein-labeled oligonucleotides showed no or weak LFG immunostaining (blue arrows), whereas (GNs with a limited uptake were still positive for LFG (white arrows). F, LFG mRNA expression in CGNs, which were not transfected or transfected with antisense or scrambled oligonucleotides (oligo) for $18 \mathrm{~h}$. LFG mRNA expression was assessed using RT-PCR and compared with actin expression shown as relative data ( $n=3$ per time point; ${ }^{*} p<0.05$ ). 
C
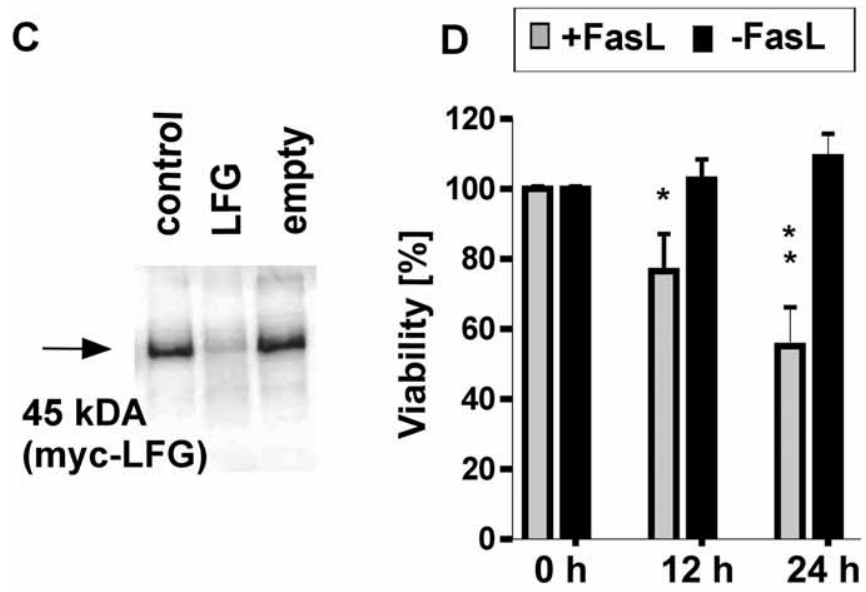

E

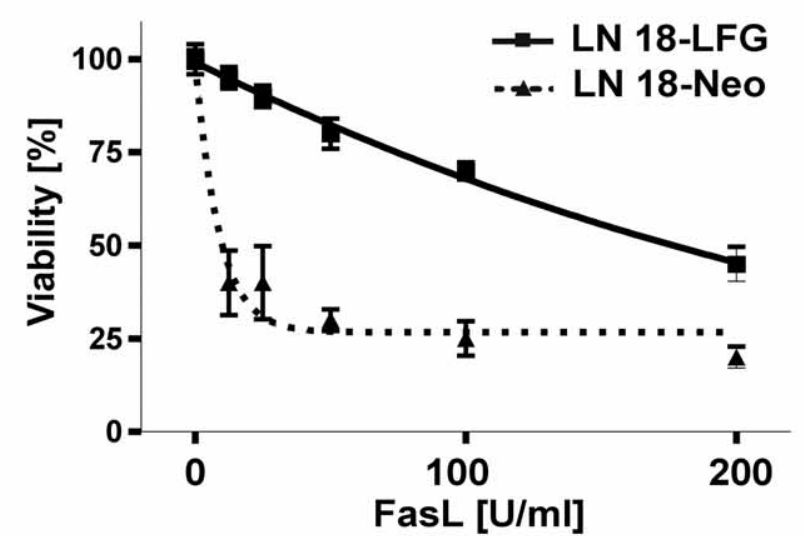

$\mathbf{F}$
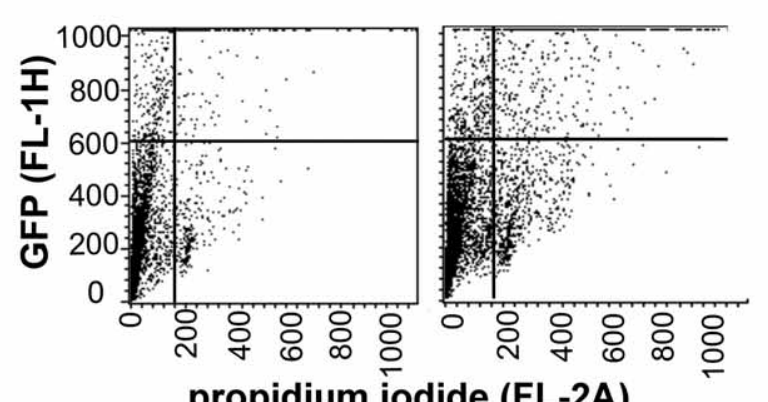

propidium iodide (FL-2A)

GFP and neo cotransfection:

UL: $265(61 \%)$

GFP and LFG cotransfection:

UR: $168(38 \%)$

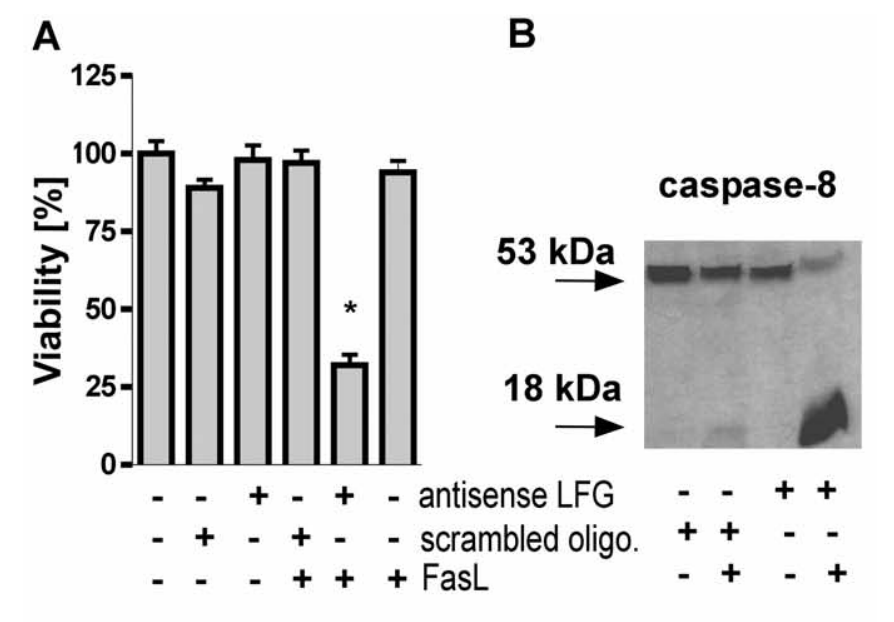

but no colocalization with GFAP (data not shown). CGNs expressed LFG mRNA but none of the 12 glioma cell lines examined (Fig. 2B). We next investigated whether LFG interacted with components of the Fas signaling pathway. LFG and Fas exhibited similar expression patterns and colocalized when double stained with specific antibodies (Fig. 2C). We found intense staining in the cytosol, cellular membranes, and neurites. Furthermore, we confirmed the previous demonstration (Somia et al., 1999) that Fas and LFG interacted physically using ectopic expression of both proteins in HEK-293 cells and subsequent coimmunoprecipitation (data not shown).

To assess whether LFG was responsible for the resistance of CGNs to FasL, we transfected CGNs transiently with LFG antisense oligonucleotides. To monitor the transfection efficacy, the oligonucleotides were conjugated to fluorescein (Fig. 2D). Approximately $70 \%$ of the neurons were transfected with LFG antisense oligonucleotides. Transfected neurons showed decreased LFG staining compared with untransfected neurons (Fig. 2E). The antisense oligonucleotide-mediated downregulation of LFG was confirmed by quantitative RT-PCR (Fig. $2 F$ ). In contrast to the antisense oligonucleotides, scrambled oligonucleotides were not effective. Cells transiently transfected with LFG antisense oligonucleotides acquired sensitivity to FasL-induced cell death and caspase- 8 cleavage (Fig. $3 A, B$ ). In contrast, CGNs transfected with scrambled oligonucleotides were still resistant to FasL (Fig. $3 D$ ). As a second method to decrease LFG expression, we used two different siRNA expressed in pSUPER-LFG (Brummelkamp et al., 2002) and directed against LFG, of which only one was successful (successful sequence is given in Materials and Methods). To confirm that the siRNA reduced LFG expression, mycLFG and pSUPER-LFG were cotransfected into HEK-293 cells. The empty vector and a scrambled siRNA sequence were used as a negative control. Only pSUPER-LFG decreased the expression of myc-tagged LFG in HEK-293 cells (Fig. 3C). The siRNAmediated reduction of LFG expression led to an increase of FasL sensitivity in CGNs (Fig. 3D). To confirm that LFG confers resistance to Fas-mediated apoptosis, we stably transfected the FasLsusceptible glioma cell line LN-18 with LFG. Approximately $80 \%$ of the cells stably ectopically expressed LFG. Expression of LFG was confirmed by immunocytochemistry (data not shown). LFG-transfected glioma cells were protected from FasL-induced cell death (Fig. 3E).

There has been a debate about whether or not potassium withdrawal-induced apoptosis is mediated by Fas. Although two

\footnotetext{
Figure 3. LFG in FasL-induced apoptosis. $\boldsymbol{A}, \boldsymbol{B}$, Incubation with antisense LFG (0.5 pM) or FasL $(500 \mathrm{U} / \mathrm{ml})$ for $24 \mathrm{~h}$ alone did not alter cell survival, whereas cotreatment resulted in cell death and caspase-8 cleavage. Exposure to scrambled oligonucleotide (oligo) alone or in combination with FasL had no such effect. Cell viability was assessed by FDA staining ( $n=3$ per condition; ${ }^{*} p<0.001$, ANOVA followed by Scheffe's post hoc test). C, To analyze the efficacy of the pSUPER-LFG siRNA vector, HEK-293 cells were cotransfected with pCDNA3-LFG and pSUPERLFG, pSUPER control, or the empty vector using FuGene. Cells were lysed at $48 \mathrm{~h}$ after transfection. $\boldsymbol{D}$, The siRNA expressed in PSUPER-LFG sensitized CGNs to FasL-induced cell death in transfected cells. $\mathrm{CaCl}_{2}$ was used for transfection. Four hours after transient cotransfection of CGNs with GFP and pSUPER (ratio of 1:2), 450 cells were evaluated per condition (- FasL, + FasL). Another 12 and $24 \mathrm{~h}$ later, the survival of the transfected (GNs was assessed by counting again the same visual fields. The viability compared with untreated conditions is given $[n=$ 3 per condition; ${ }^{*} p<0.05,{ }^{* *} p<0.01$ compared with untreated $(0 \mathrm{~h})$ condition]. $\boldsymbol{E}$, Stable overexpression of LFG protected LN-18 glioma cells from FasL-induced death. Viability was assessed by crystal violet staining ( $n=3$ per time point and condition). $\boldsymbol{F}, \mathrm{LN}-18$ glioma cells were protected from FasL-induced cell death when transiently cotransfected with GFP and LFG (GFP/LFG of 2:1). Cell death was assessed $18 \mathrm{~h}$ after addition of $50 \mathrm{U} / \mathrm{ml}$ FasL by propidium iodide staining, followed by flow cytometric analysis of DNA content in GFP-positive cells.
} 
groups reported that neutralizing antiFasL antibodies protected from potassium withdrawal-induced apoptosis (LeNiculescu et al., 1999; Castiglione et al., 2004), we and others did not find a role for Fas in this system (Gerhardt et al., 2001; Putcha et al., 2002). In agreement with our previous results, we did not find a protection from potassium withdrawal-induced apoptosis after forced expression of LFG in CGNs (data not shown).

To show that LFG prevents DNA loss as well as cell death, we cotransfected LN-18 glioma cells with GFP and LFG. After incubation with $50 \mathrm{U} / \mathrm{ml}$ FasL for $18 \mathrm{~h}$, we determined DNA content by propidium iodide staining and subsequent flow cytometry (Fig. $3 F$ ). Whereas $61 \%$ of the GFP control cells exhibited reduced DNA content, this was true for only $34 \%$ of the cells cotransfected with GFP and LFG.

FasL resistance of CGNs is mediated by phosphatidylinositol 3-kinasedependent expression of LFG

The IGF-1/phosphatidylinositol 3-kinase (PI 3-kinase)-mediated pathway signals survival in paradigms of neuronal death, e.g., in potassium withdrawal-induced apoptosis of CGNs (Miller et al., 1997; D'Mello et al., 1998; Gleichmann et al., 2000). CGNs cultured in medium containing $10 \%$ FCS did not die when exposed to the PI 3-kinase inhibitors wortmannin or LY294002 [2-(4-morpholinyl)-8-phenyl1(4H)-benzopyran-4-one]. In contrast, treatment of CGNs with PI 3-kinase inhibitors in combination with FasL concentration dependently induced cell death (Fig. 4A). The combination of the PI 3-kinase inhibitor wortmannin and FasL induced caspase-dependent fodrin cleavage, whereas either treatment alone was ineffective (Fig. 4B). Activation of caspase- 8 and caspase- 3 was observed after coincubation of CGNs with wortmannin and FasL for 6 h (Fig. 4C).

We then asked whether the increased sensitivity of CGNs treated with PI 3-kinase inhibitors resulted from decreased expression of LFG. Treatment with the PI 3-kinase inhibitor LY294002 induced a time-dependent decrease of LFG mRNA (Fig. 4D) and protein (Fig. $4 E$ ) expression. After $12 \mathrm{~h}$, mRNA expression was reduced to $<10 \%$ compared with untreated cells (Fig. 4D).

Because FasL-induced cell death in motor neurons is mediated by a DAXX-ASK1-p38 pathway (Raoul et al., 2002), we questioned whether or not the classical caspase-8-dependent pathway is relevant in CGNs. The activation of caspase- 8 is a key event because its inhibition by $100 \mu \mathrm{M}$ of a specific inhibitor of caspase-8, IETD-fmk [Ile$\mathrm{Glu}(\mathrm{OMe})-\mathrm{Thr}-\mathrm{Asp}(\mathrm{OMe})$-fluoromethyl ketone], almost completely prevented apoptosis and fodrin cleavage in CGNs treated with FasL and wortmannin (Fig. 5A,B). In contrast, IETD-fmk did not block potassium withdrawal-induced apoptosis (Fig. $5 A$ ), which is mediated via the endogenous, mitochondrial pathway involving the translocation of cytochrome $c$ to the cytosol and the sequential activation of caspase- 9 and caspase- 3 (Gerhardt et al., 2001). To further confirm the interaction between the PI 3-kinase pathway and Fas, we treated CGNs from lpr mice with the activating Fas antibody Jo2 and wortmannin or LY294002, respectively (Fig. 5C). lpr mice lack a functional Fas receptor. Whereas CGNs from wild-type controls died when exposed to wortmannin and FasL or Jo2, CGNs from lpr mice were resistant (Fig. 5C).

To confirm that the increased sensitivity of CGNs to FasLinduced apoptosis after PI 3-kinase inhibition is caused by decreased LFG expression, we tested whether transient overexpression of LFG in this paradigm is protective. In contrast to control transfection with GFP, LFG overexpression provided almost complete protection against FasL-induced apoptosis after PI 3-kinase inhibition (Fig. 5D).

The LFG promoter is regulated by PI 3-kinase activity To further investigate the regulation of LFG transcription, we cloned the rat LFG promoter into the reporter plasmid pGL3basic (Promega). Because of the poor transfection rates obtained 
A

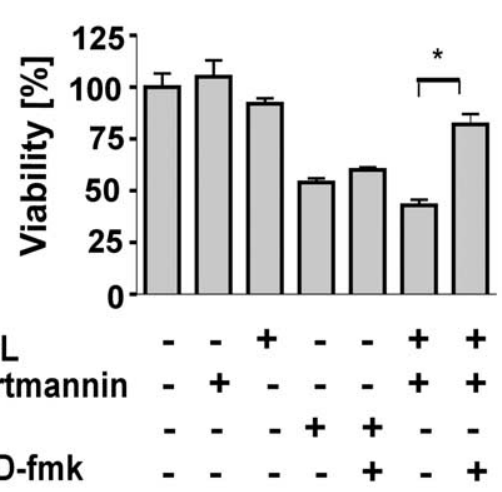

C

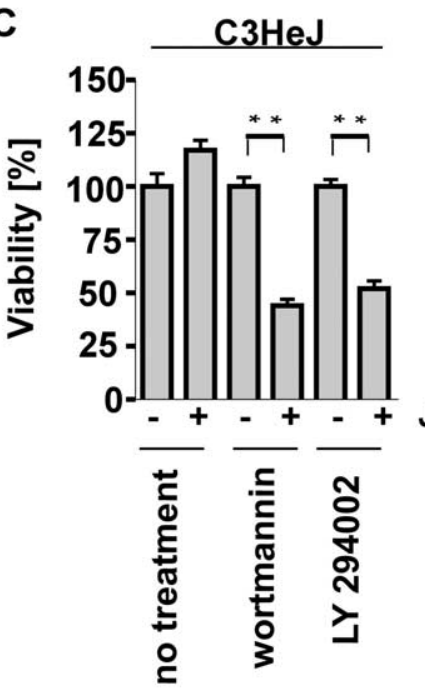

B

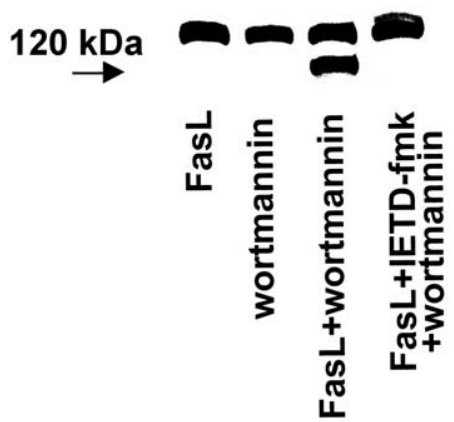

D

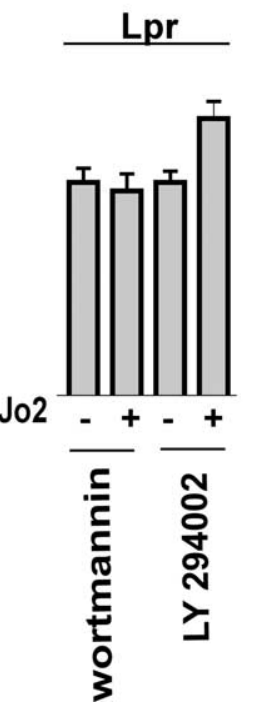

Figure 5. Activation of caspase-8 in FasL induced apoptosis of CGNs. $A, B$, The specific caspase-8 inhibitor IETD-fmk (100 $\mu \mathrm{M})$ prevented cell death and fodrin cleavage induced by the combination of FasL $(500 \mathrm{U} / \mathrm{ml})$ and wortmannin $(0.2 \mu \mathrm{m})$. Cell viability of CGNs was measured by FDA staining after $24 \mathrm{~h}$ of treatment with substances as indicated $\left(n=3\right.$ per condition; ${ }^{*} p<0.05$, ANOVA followed by Scheffe's post hoc test). LK, Low potassium. C, GGNs from /pr mice were protected against cell death induced by the combination of the Fas agonistic antibody Jo2 $(20 \mu \mathrm{g} / \mathrm{ml})$ with wortmannin $(0.2 \mu \mathrm{M})$ or LY294002 (10 $\mu \mathrm{M})$, whereas (GNs obtained from strain-specific controls underwent apoptosis ( $n=3$ per condition; ${ }^{* *} p<0.01$, ANOVA followed by Scheffe's post hoc test). D, CGNs were cotransfected with GFP and pcDNA3-LFG or an empty vector (ratio 2:1) using the GeneGun. With this method $\sim 2-5 \%$ of cells were transfected. Approximately $300 \mathrm{GFP}$-positive cells in two wells per condition were evaluated per condition (LFG vs empty vector). CGNs were then treated with the combination of $500 \mathrm{U} / \mathrm{ml}$ FasL and $0.2 \mu \mathrm{m}$ wortmannin. Another $24 \mathrm{~h}$ later, the survival of the transfected CGNs was assessed by counting again the same visual fields. The viability compared with pretreatment conditions is given $\left({ }^{*} p<0.05\right.$; ANOVA followed by Scheffe's post hoc test).

with CGNs, we chose the rat pheochromocytoma cell line PC12 for the reporter gene experiments. PC12 cells endogenously express LFG (data not shown). Accordingly, there was a marked activation of the LFG reporter plasmid (LFG-Luc) in PC12 cells without stimulation (Fig. 6A). Treatment with NGF, an activator of PI 3-kinase, further increased the LFG-Luc signal. After incubation with the PI 3-kinase inhibitor LY294002, the activity of the LFG promoter was reduced close to background levels, suggesting that a PI 3-kinase-dependent signaling pathway is the main activator of LFG transcription in neuronal cells. This suppression of LFG activation was not reversed by the addition of NGF (Fig. 6A).

The activation of Akt/PKB by PI 3-kinase is essential for neuronal survival (Burgering and Coffer, 1995; Crowder and Freeman, 1998; Chan et al., 1999; Datta et al., 1999). We therefore asked whether Akt/PKB is involved in the regulation of LFG transcription. Cotransfection of the LFG reporter plasmid with DN-
Akt/PKB but not with an empty plasmid blocked LFG reporter activity (Fig. 6B). Conversely, overexpression of gag-Akt/ PKB (Bellacosa et al., 1991) was followed by an increase in LFG reporter activity. Furthermore, there was no reduction of LFG-Luc activation after addition of LY294002 if cells had been transfected with gag-Akt/PKB. Together, these results show an essential role of the PI 3-kinaseAkt/PKB signaling pathway in the regulation of LFG transcription.

Akt/PKB activates various transcription factors, including forkhead transcription factors and nuclear factor $\kappa \mathrm{B}(\mathrm{NF} \kappa \mathrm{B})$. The rat LFG promoter cloned into LFGLuc contained a consensus site for NF $\kappa \mathrm{B}$. If $\mathrm{NF} \kappa \mathrm{B}$ was of importance for the transcription of LFG, the inhibitory protein $\mathrm{I} \kappa \mathrm{B}$ should suppress the LFG-Luc activation. Cotransfection of PC12 cells with $\mathrm{I} \kappa \mathrm{B}$ and LFG-Luc led to a significant reduction of the LFG reporter activation compared with cells transfected with a control plasmid. Still, there was a marked activity left, suggesting that there is more than one transcription factor involved in the regulation of LFG (Fig. 6C).

\section{Discussion}

Fas is a member of the TNF/NGF receptor family that triggers apoptosis. CGNs express Fas but are resistant to exogenous FasL or agonistic Fas antibodies (Gerhardt et al., 2001; Putcha et al., 2002), although this has been disputed by others (LeNiculescu et al., 1999; Hou et al., 2002). The expression of c-FLIP appears to mediate this resistance in lymphocytes, endothelial cells, and differentiated spinal motor neurons (Irmler et al., 1997; Thome et al., 1997; Raoul et al., 1999; Scaffidi et al., 1999; Yeh et al., 2000; Panka and Mier, 2003). At DIV 8, this resistance appears to be independent of FLIP and, rather, attributable to LFG expression (Fig. 1C-E). Using a genetic screen, LFG was identified as protecting cells uniquely from FasL but not from TNF- $\alpha$ (Somia et al., 1999). We here show that CGNs, but not glial cells, expressed LFG. LFG colocalized (Fig. 2C) and physically interacted (Somia et al., 1999, and data not shown) with Fas. Furthermore, inhibition of LFG expression by treatment with antisense oligonucleotides or siRNA rendered CGNs susceptible to FasL (Fig. $3 A, D)$. In contrast, expression of LFG in the FasL-susceptible glioma cell line LN-18 provided protection from FasL-induced cell death, proving that indeed LFG inhibits apoptosis mediated by Fas signaling (Fig. $3 E, F$ ).

The IGF-1-PI 3-kinase-Akt/PKB kinase-mediated pathway signals survival in paradigms of neuronal survival, e.g., in potassium withdrawal-induced apoptosis of CGNs (Miller et al., 1997; D’Mello et al., 1998; Gleichmann et al., 2000; Subramaniam et al., 2003). PI 3-kinase-generated phosphoinositides are important second messengers in neurons that are activated by various 
growth factors. They activate Akt/PKB, a kinase that interferes with the apoptotic cascades by phosphorylation of proteins such as Bax or caspase-9. Inhibition of $\mathrm{Akt} / \mathrm{PKB}$ activation induces Fasdependent apoptosis in endothelial cells, likely mediated by a downregulation of FLIP (Panka et al., 2001; Panka and Mier, 2003). Coexpression of Fas with constitutively active PI 3-kinase in COS7 cells resulted in protection from FasL-induced death (Hausler et al., 1998). An interaction between PI 3-kinase-Akt/PKB signaling and Fas has been described previously in T-cells in which PI 3-kinase inhibited the formation of Fas aggregates by mediating changes in the actin cytoskeleton (Varadhachary et al., 1999, 2001).

In our study, Fas-mediated apoptosis of CGNs was regulated by PI 3-kinaseAkt/PKB-dependent expression of LFG. Inhibition of PI 3-kinase activity with specific inhibitors was followed by a massive reduction of LFG mRNA and protein expression (Fig. 4D,E). This downregulation caused increased sensitivity to FasLinduced apoptosis (Fig. $4 A-C$ ). In other cell types, including $\mathrm{T}$ lymphocytes, endothelial cells, and different tumor cell lines, PI 3-kinase-Akt/PKB inhibition sensitizes to FasL toxicity (Hausler et al., 1998; Varadhachary et al., 1999, 2001; Panka et al., 2001; Suhara et al., 2001; Ivanov et al., 2002; Jones et al., 2002; Panka and Mier, 2003). As potential mechanisms an upregulation of FLIP (Panka et al., 2001; Panka and Mier, 2003), changes in the actin cytoskeleton (Varadhachary et al., 1999, 2001), Fas (Ivanov et al., 2002), or FasL expression (Suhara et al., 2001) or inhibition of procaspase- 8 translocation to the death-inducing signaling complex (Jones et al., 2002) have been discussed. In CGNs, it is unlikely that mechanisms other than LFG are involved in this increased sensitivity to FasL, because overexpression of LFG completely protected CGNs against FasL toxicity after inhibition of PI 3-kinase activity (Fig. 5D).

In contrast to some reports (Datta et al., 1997; Miller et al., 1997; Shimoke et al., 1999) but in line with previous reports (Gleichmann et al., 2000; Subramaniam et al., 2003), we did not observe death in CGNs after the exposure to wortmannin or LY294002 as long as CGNs were not withdrawn from potassium. This might reflect differences in culture conditions.

To further investigate the intracellular signaling cascade regulating LFG expression, we cloned its promoter sequence into a reporter plasmid. Using this tool, we were able to investigate potential regulatory proteins involved in the regulation of LFG expression. The kinase Akt/PKB turned out to be a crucial member of the signaling cascade. Overexpression of DN-Akt/PKB resulted in a complete suppression of LFG-Luc activity (Fig. $6 \mathrm{~B}$ ). Furthermore, the transient overexpression of constitutive active Akt/PKB overcame the suppression of LFG transcription by PI 3-kinase inhibitors.

Akt/PKB activates several transcription factors, among them $\mathrm{NF} \kappa \mathrm{B}$. Inhibition of $\mathrm{NF} \kappa \mathrm{B}$ by transient overexpression of $\mathrm{I} \kappa \mathrm{B}$, an endogenous inhibitor of $\mathrm{NF} \kappa \mathrm{B}$, was followed by a marked reduction of LFG-Luc activity, indicating that $\mathrm{NF} \kappa \mathrm{B}$ is involved in the transcriptional regulation of LFG expression.

We thus show here for the first time that expression of LFG is mediated by the PI 3-kinase-Akt/PKB pathway. Activators of PI
B

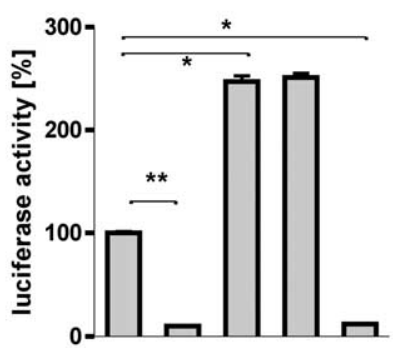

C

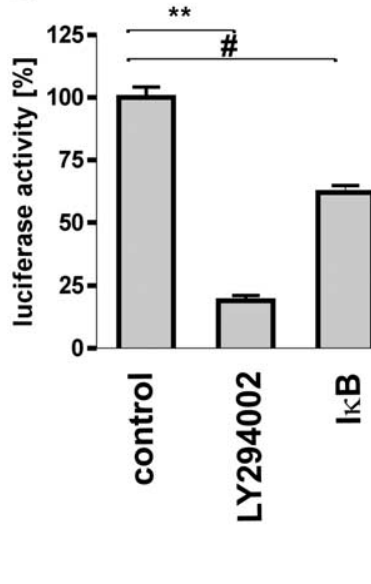

inase, e.g., IGF-1 and several neurotrophins, including NGF, neurotrophin-3, and neurotrophin-4, provide neuroprotection in several paradigms of neuronal death (Zheng et al., 2002). Activation of the PI 3-kinase-Akt/PKB pathway protects cells through different pathways, e.g., phosphorylation of caspase-9, Bad, or forkhead family transcription factors (Datta et al., 1999). These molecular modifications all affect the endogenous, mitochondrial death pathway. In addition, in CGNs, Brunet et al. (1999) identified a forkhead transcription factor (FKHLR1) to be negatively regulated by $\mathrm{Akt} / \mathrm{PKB}$ activation, to be retained in the cytoplasm by 14-3-3, and that FasL is a major mediator of this transcription factor (Brunet et al., 1999). The transcription of LFG can be added here as an important downstream target of Akt/PKB. By identifying LFG transcription as another target of Akt/PKB, this adds to the mechanisms of how neurons are protected from FasL toxicity.

In experimental conditions of epilepsy (Henshall et al., 2002), progressive motor neuropathy (Wagey et al., 2001), and global brain ischemia (Noshita et al., 2001), PI 3-kinase and/or Akt activities are differentially regulated, and inhibition of PI 3-kinase further exacerbates neuronal death. There is increasing interest in the role and regulation of Fas in neurons of the CNS, because its inactivation in $l$ pr mice or with antagonistic antibodies confers protection in animal models of stroke and multiple sclerosis (Martin-Villalba et al., 1999, 2001; Waldner et al., 1997). As a consequence, activation of Fas must be considered as a key event for the induction of neuronal apoptosis in these diseases. In contrast to these results, healthy neurons do not appear to be vulnerable to FasL-mediated toxicity because neurons express LFG throughout the brain. At the moment, it remains a challenging hypothesis whether, in disease conditions such as ischemia, Parkinson's disease, or multiple sclerosis, the expression of LFG is downregulated, resulting in a sensitization of the Fas/FasL cell death pathway. Activation of the PI 3-kinase-LFG pathway might become a promising target for the acute treatment of neurological disorders.

\section{References}

Bechmann I, Mor G, Nilsen J, Eliza M, Nitsch R, Naftolin F (1999) FasL (CD95L, Apo1L) is expressed in the normal rat and human brain: evidence for the existence of an immunological brain barrier. Glia 27:62-74. Bellacosa A, Testa JR, Staal SP, Tsichlis PN (1991) A retroviral oncogene, 
akt, encoding a serine-threonine kinase containing an SH2-like region. Science 254:274-277.

Brummelkamp TR, Bernards R, Agami R (2002) A system for stable expression of short interfering RNAs in mammalian cells. Science 296:550-553.

Brunet A, Bonni A, Zigmond MJ, Lin MZ, Juo P, Hu LS, Anderson MJ, Arden KC, Blenis J, Greenberg ME (1999) Akt promotes cell survival by phosphorylating and inhibiting a Forkhead transcription factor. Cell 96:857-868.

Burgering BMT, Coffer PJ (1995) Protein kinase B (c-Akt) in phosphatidylinositol-3-OH kinase signal transduction. Nature 376:599-602.

Castiglione M, Spinsanti P, Iacovelli L, Lenti L, Martini F, Gradini R, Di Giorgi Gerevini V, Caricasole A, Caruso A, De Maria R, Nicoletti F, Melchiorri D (2004) Activation of Fas receptor is required for the increased formation of the disialoganglioside GD3 in cultured cerebellar granule cells committed to apoptotic death. Neuroscience 126:889-898.

Chan TO, Rittenhouse SE, Tsichlis PN (1999) AKT/PKB and other D3 phosphoinositide-regulated kinases: kinase activation by phosphoinositide-dependent phosphorylation. Annu Rev Biochem 68:965-1014.

Cheema ZF, Wade SB, Sata M, Walsh K, Sohrabji F, Miranda RC (1999) Fas/Apo [apoptosis]-1 and associated proteins in the differentiating cerebral cortex: induction of caspase-dependent cell death and activation of NF- $\kappa$ B. J Neurosci 19:1754-1770.

Clementi R, Dagna L, Dianzani U, Dupre L, Dianzani I, Ponzoni M, Cometa A, Chiocchetti A, Sabbadini MG, Rugarli C, Ciceri F, Maccario R, Locatelli F, Danesino C, Ferrarini M, Bregni M (2004) Inherited perforin and Fas mutations in a patient with autoimmune lymphoproliferative syndrome and lymphoma. N Engl J Med 351:1419-1424.

Crowder RJ, Freeman RS (1998) Phosphatidylinositol 3-kinase and Akt protein kinase are necessary and sufficient for the survival of nerve growth factor-dependent sympathetic neurons. J Neurosci 18:2933-2943.

Datta SR, Dudek H, Tao X, Masters S, Fu H, Gotoh Y, Greenberg ME (1997) Akt phosphorylation of BAD couples survival signals to the cell-intrinsic death machinery. Cell 91:231-241.

Datta SR, Brunet A, Greenberg ME (1999) Cellular survival: a play in three Akts. Genes Dev 13:2905-2927.

D’Mello SR, Aglieco F, Roberts MR, Borodezt K, Haycock JW (1998) A DEVD-inhibited caspase other than CPP32 is involved in the commitment of cerebellar granule neurons to apoptosis induced by $\mathrm{K}^{+}$deprivation. J Neurochem 70:1809-1818.

Drappa J, Vaishnaw AK, Sullivan KE, Chu JL, Elkon KB (1996) Fas gene mutations in the Canale-Smith syndrome, an inherited lymphoproliferative disorder associated with autoimmunity. $N$ Engl J Med 335:1643-1649.

Dyer BW, Ferrer FA, Klinedinst DK, Rodriguez R (2000) A noncommercial dual luciferase enzyme assay system for reporter gene analysis. Anal Biochem 282:158-161.

Felderhoff-Mueser U, Taylor DL, Greenwood K, Kozma M, Stibenz D, Joashi UC, Edwards AD, Mehmet H (2000) Fas/CD95/APO-1 can function as a death receptor for neuronal cells in vitro and in vivo and is upregulated following cerebral hypoxic-ischemic injury to the developing rat brain. Brain Pathol 10:17-29.

French LE, Hahne M, Viard I, Radlgruber G, Zanone R, Becker K, Muller C, Tschopp J (1996) Fas and Fas ligand in embryos and adult mice: ligand expression in several immune-privileged tissues and coexpression in adult tissues characterized by apoptotic cell turnover. J Cell Biol 133:335-343.

Gerhardt E, Kügler S, Leist M, Beier C, Berliocchi L, Volbracht C, Weller M, Bähr M, Nicotera P, Schulz JB (2001) Cascade of caspase-activation in potassium-deprived cerebellar granule neurons: targets for treatment with peptide and protein inhibitors of apoptosis. Moll Cell Neurosci 17:717-731.

Gleichmann M, Weller M, Schulz JB (2000) Insulin-like growth factor-1mediated protection from neuronal apoptosis is linked to phosphorylation of the pro-apoptotic protein BAD but not to inhibition of cytochrome $\mathrm{c}$ translocation in rat cerebellar neurons. Neurosci Lett 282:69-72.

Gleichmann M, Buchheim G, El-Bizri H, Yokota Y, Klockgether T, Kugler S, Bahr M, Weller M, Schulz JB (2002) Identification of inhibitor-ofdifferentiation 2 (Id2) as a modulator of neuronal apoptosis. J Neurochem 80:755-762.

Green DR, Ferguson TA (2001) The role of Fas ligand in immune privilege. Nat Rev Mol Cell Biol 2:917-924.

Hausler P, Papoff G, Eramo A, Reif K, Cantrell DA, Ruberti G (1998) Pro- tection of CD95-mediated apoptosis by activation of phosphatidylinositide 3-kinase and protein kinase B. Eur J Immunol 28:57-69.

Henshall DC, Araki T, Schindler CK, Lan JQ, Tiekoter KL, Taki W, Simon RP (2002) Activation of Bcl-2-associated death protein and counterresponse of Akt within cell populations during seizure-induced neuronal death. J Neurosci 22:8458-8465.

Holzelova E, Vonarbourg C, Stolzenberg MC, Arkwright PD, Selz F, Prieur AM, Blanche S, Bartunkova J, Vilmer E, Fischer A, Le Deist F, RieuxLaucat F (2004) Autoimmune lymphoproliferative syndrome with somatic Fas mutations. N Engl J Med 351:1409-1418.

Hou ST, Xie X, Baggley A, Park DS, Chen G, Walker T (2002) Activation of the $\mathrm{Rb} / \mathrm{E} 2 \mathrm{~F} 1$ pathway by the nonproliferative p38 MAPK during Fas (APO1/ CD95)-mediated neuronal apoptosis. J Biol Chem 277:48764-48770.

Irmler M, Thome M, Hahne M, Schneider P, Hofmann K, Steiner V, Bodmer JL, Schroter M, Burns K, Mattmann C, Rimoldi D, French LE, Tschopp J (1997) Inhibition of death receptor signals by cellular FLIP. Nature 388:190-195.

Ivanov VN, Krasilnikov M, Ronai Z (2002) Regulation of Fas expression by STAT3 and c-Jun is mediated by phosphatidylinositol 3-kinase-AKT signaling. J Biol Chem 277:4932-4944.

Jänicke RU, Ng P, Sprengart ML, Porter AG (1998) Caspase-3 is required for alpha-fodrin cleavage but dispensable for cleavage of other death substrates in apoptosis. J Biol Chem 273:15540-15545.

Jones RG, Elford AR, Parsons MJ, Wu L, Krawczyk CM, Yeh WC, Hakem R, Rottapel R, Woodgett JR, Ohashi PS (2002) CD28-dependent activation of protein kinase B/Akt blocks Fas-mediated apoptosis by preventing death-inducing signaling complex assembly. J Exp Med 196:335-348.

Kohrmann M, Haubensak W, Hemraj I, Kaether C, Lessmann VJ, Kiebler MA (1999) Fast, convenient, and effective method to transiently transfect primary hippocampal neurons. J Neurosci Res 58:831-835.

Kovac AD, Grammig J, Mahlo J, Steiner B, Roth K, Nitsch R, Bechmann I (2002) Comparison of neuronal density and subfield sizes in the hippocampus of CD95L-deficient (gld), CD95-deficient (lpr) and nondeficient mice. Eur J Neurosci 16:159-163.

Le-Niculescu H, Bonfoco E, Kasuya Y, Claret FX, Green DR, Karin M (1999) Withdrawal of survival factors results in activation of the JNK pathway in neuronal cells leading to Fas ligand induction and cell death. Mol Cell Biol 19:751-763.

Martin-Villalba A, Herr I, Jeremias I, Hahne M, Brandt R, Vogel J, Schenkel J, Herdegen T, Debatin KM (1999) CD95 ligand (Fas-L/APO-1L) and tumor necrosis factor-related apoptosis-inducing ligand mediate ischemiainduced apoptosis in neurons. J Neurosci 19:3809-3817.

Martin-Villalba A, Hahne M, Kleber S, Vogel J, Falk W, Schenkel J, Krammer PH (2001) Therapeutic neutralization of CD95-ligand and TNF attenuates brain damage in stroke. Cell Death Differ 8:679-686.

Miller TM, Tansey MG, Johnson Jr EM, Creedon DJ (1997) Inhibition of phosphatidylinositol 3-kinase activity blocks depolarization- and insulinlike growth factor I-mediated survival of cerebellar granule cells. J Biol Chem 272:9847-9853.

Noshita N, Lewen A, Sugawara T, Chan PH (2001) Evidence of phosphorylation of Akt and neuronal survival after transient focal cerebral ischemia in mice. J Cereb Blood Flow Metab 21:1442-1450.

Panka DJ, Mier JW (2003) Canstatin inhibits Akt activation and induces Fasdependent apoptosis in endothelial cells. J Biol Chem 278:37632-37636.

Panka DJ, Mano T, Suhara T, Walsh K, Mier JW (2001) Phosphatidylinositol 3-kinase/Akt activity regulates c-FLIP expression in tumor cells. J Biol Chem 276:6893-6896.

Park C, Sakamaki K, Tachibana O, Yamashima T, Yamashita J, Yonehara S (1998) Expression of fas antigen in the normal mouse brain. Biochem Biophys Res Commun 252:623-628.

Putcha GV, Harris CA, Moulder KL, Easton RM, Thompson CB, Johnson Jr EM (2002) Intrinsic and extrinsic pathway signaling during neuronal apoptosis: lessons from the analysis of mutant mice. J Cell Biol 157:441-453.

Raoul C, Henderson CE, Pettmann B (1999) Programmed cell death of embryonic motoneurons triggered through the Fas death receptor. J Cell Biol 147:1049-1062.

Raoul C, Estevez AG, Nishimune H, Cleveland DW, deLapeyriere O, Henderson CE, Haase G, Pettmann B (2002) Motoneuron death triggered by a specific pathway downstream of Fas. Potentiation by ALS-linked SOD1 mutations. Neuron 35:1067-1083.

Rensing-Ehl A, Frei K, Flury R, Matiba B, Mariani SM, Weller M, Aebischer P, 
Krammer PH, Fontana A (1995) Local Fas/APO-1 (CD95) ligandmediated tumor cell killing in vivo. Eur J Immunol 25:2253-2258.

Saas P, Walker PR, Hahne M, Quiquerez AL, Schnuriger V, Perrin G, French L, Van Meir EG, de Tribolet N, Tschopp J, Dietrich PY (1997) Fas ligand expression by astrocytoma in vivo: maintaining immune privilege in the brain? J Clin Invest 99:1173-1178.

Scaffidi C, Schmitz I, Krammer PH, Peter ME (1999) The role of c-FLIP in modulation of CD95-induced apoptosis. J Biol Chem 274:1541-1548.

Schneider P, Holler N, Bodmer JL, Hahne M, Frei K, Fontana A, Tschopp J (1998) Conversion of membrane-bound Fas(CD95) ligand to its soluble form is associated with downregulation of its proapoptotic activity and loss of liver toxicity. J Exp Med 187:1205-1213.

Schulz JB, Weller M, Klockgether T (1996) Potassium deprivation-induced apoptosis of cerebellar granule neurons: a sequential requirement for new mRNA and protein synthesis, ICE-like protease activity, and reactive oxygen species. J Neurosci 16:4696-4706.

Schweitzer B, Taylor V, Welcher AA, McClelland M, Suter U (1998) Neural membrane protein 35 (NMP35): a novel member of a gene family which is highly expressed in the adult nervous system. Mol Cell Neurosci 11:260-273.

Schweitzer B, Suter U, Taylor V (2002) Neural membrane protein 35/Lifeguard is localized at postsynaptic sites and in dendrites. Brain Res Mol Brain Res 107:47-56.

Shimoke K, Yamagishi S, Yamada M, Ikeuchi T, Hatanaka H (1999) Inhibition of phosphatidylinositol 3-kinase activity elevates c-Jun N-terminal kinase activity in apoptosis of cultured cerebellar granule neurons. Brain Res Dev Brain Res 112:245-253.

Somia NV, Schmitt MJ, Vetter DE, Van Antwerp D, Heinemann SF, Verma IM (1999) LFG: an anti-apoptotic gene that provides protection from Fas-mediated cell death. Proc Natl Acad Sci USA 96:12667-12672.

Subramaniam S, Strelau J, Unsicker K (2003) Growth differentiation factor-15 prevents low potassium-induced cell death of cerebellar granule neurons by differential regulation of Akt and ERK pathways. J Biol Chem 278:8904-8912.

Suhara T, Mano T, Oliveira BE, Walsh K (2001) Phosphatidylinositol 3-kinase/Akt signaling controls endothelial cell sensitivity to Fas-mediated apoptosis via regulation of FLICE-inhibitory protein (FLIP). Circ Res 89:13-19.

Thome M, Schneider P, Hofmann K, Fickenscher H, Meinl E, Neipel F, Mattmann C, Burns K, Bodmer JL, Schroter M, Scaffidi C, Krammer PH, Peter ME, Tschopp J (1997) Viral FLICE-inhibitory proteins (FLIPs) prevent apoptosis induced by death receptors. Nature 386:517-521.

Varadhachary AS, Peter ME, Perdow SN, Krammer PH, Salgame P (1999) Selective up-regulation of phosphatidylinositol 3'-kinase activity in Th2 cells inhibits caspase- 8 cleavage at the death-inducing complex: a mechanism for Th2 resistance from Fas-mediated apoptosis. J Immunol 163:4772-4779.

Varadhachary AS, Edidin M, Hanlon AM, Peter ME, Krammer PH, Salgame P (2001) Phosphatidylinositol 3'-kinase blocks CD95 aggregation and caspase- 8 cleavage at the death-inducing signaling complex by modulating lateral diffusion of CD95. J Immunol 166:6564-6569.

Wagey R, Lurot S, Perrelet D, Pelech SL, Sagot Y, Krieger C (2001) Phosphatidylinositol 3-kinase activity in murine motoneuron disease: the progressive motor neuropathy mouse. Neuroscience 103:257-266.

Waldner H, Sobel RA, Howard E, Kuchroo VK (1997) Fas- and FasLdeficient mice are resistant to induction of autoimmune encephalomyelitis. J Immunol 159:3100-3103.

Weller M, Frei K, Groscurth P, Krammer PH, Yonekawa Y, Fontana A (1994) Anti-Fas/APO-1 antibody-mediated apoptosis of cultured human glioma cells. Induction and modulation of sensitivity by cytokines. J Clin Invest 94:954-964.

Weller M, Malipiero U, Rensing-Ehl A, Barr PJ, Fontana A (1995) Fas/APO-1 gene transfer for human malignant glioma. Cancer Res 55:2936-2944.

Weller M, Weinstock C, Will C, Wagenknecht B, Dichgans J, Lang F, Gulbins E (1997) CD95-dependent T cell killing by glioma cells expressing CD95 ligand: more on tumor immune escape, the CD95 counterattack, and the immune privilege of the brain. Cell Physiol Biochem 7:282-288.

Yeh WC, Itie A, Elia AJ, Ng M, Shu HB, Wakeham A, Mirtsos C, Suzuki N, Bonnard M, Goeddel DV, Mak TW (2000) Requirement for Casper (cFLIP) in regulation of death receptor-induced apoptosis and embryonic development. Immunity 12:633-642.

Zheng WH, Kar S, Quirion R (2002) FKHRL1 and its homologs are new targets of nerve growth factor Trk receptor signaling. J Neurochem 80:1049-1061. 